\title{
Decomposition of form surfaces for planning of machining
}

Jozef Beňo, Jozef Stahovec, Peter Ižol, Miroslav Tomáš

Technical University of Košice, Faculty of Mechanical Engineering, Department of Technology and Materials, Street Mäsiarska 74, 04001 Košice, Slovakia. jozef.beno@tuke.sk, jozef.stahovec@tuke.sk, peter.izol@tuke.sk, miroslav.tomas@tuke.sk

Paper deals with manufacturability of form surfaces produced by 3D milling operations. Based on decomposition of form surfaces, which are designed by CAD, virtual elementary operations of milling form surfaces are presented. Some typical engineering components with form surfaces were designed to analyse their features. Forms surfaces are classified to give review of dimensionless basic shapes. Review of milling strategies is introduced to select planning of machining of surfaces taken from virtual components. A representative component was analysed in order to obtain overall length of tool paths related to the elementary surfaces. Examples of process planning of elementary surfaces which conform to their classification are discussed. Combination of milling strategies to achieve desired surface finish is introduced.

Keywords: Form surface, CAM, SolidCAM, virtual representation, process planning

\section{Acknowledgement}

Presented results have been achieved within 1/0500/12 VEGA Project: Research on Quality Improvement when Milling Formed Surfaces by Advanced Coated Tools, supported by Ministry of Education, Science, Research and Sports of Slovakia.

\section{References}

[1] HUMIENNY Z. et. al. (2001). Geometrical Product Specification. Warsaw University Technology Printing House, ISBN 83-912190-8-9.

[2] GROTE K. H., ANTONSON E. K. (2009). Springer Handbook of Mechanical Engineering, 2009, 1580 p, ISBN 978-3-540-49131-6.

[3] LU, Y., GADH, R., TAUTGES, T.J. (2001). Feature based hex meshing methodology: feature recognition and volume decomposition. Computer-Aided Design, Vol. 33, No. 3, pp. 221 - 232.

[4] KI, D., LEE, K., (2002). Part decomposition for die pattern machining. Journal of Materials Processing Technology, Vol. 130 - 131, pp. $599-607$.

[5] LI, B., LIU, J. (2002). Detail feature recognition and decomposition in solid model. Computer-Aided Design, Vol. 34, No. 5, pp. $405-414$.

[6] WOO, Y. (2003). Fast cell-based decomposition and applications to solid modelling. Computer-Aided Design, Vol. 35, No. 11, pp. $969-977$.

[7] JINYUAN, J., BACIU, G., KWOK, K. (2004). Quadric decomposition for computing the intersections of surfaces of revolution. Graphical Models, Vol. 66, No. 5, $303-330$.

[8] BESPALOV, D., REGLI, W.C, SHOKOUFANDEH, A. (2006). Local feature extraction and matching partial objects. Computer-Aided Design, Vol. 38, No. 9, pp.1020 - 1037.

[9] LIEN, J., AMATO, N. (2006). Approximate convex decomposition of polygons. Computational Geometry, Vol. 35, No. $1-2$, pp. $100-123$.

[10] SUN, G., SEQUIN, C.H., WRIGHT, P.K. (2001). Operation decomposition for freeform surface features in process planning. Computer-Aided Design, Vol. 33, No. 9, pp. $621-636$.

[11] CHENG, H., LO, CH., CHU, CH., KIM, Y.S. (2011). Shape similarity measurement for 3D mechanical part using D2 shape distribution and negative feature decomposition. Computers in Industry, Vol. 62, No. 3, pp. 269 280.

[12] XIAN, C., GAO, S., ZHANG, T. (2011). An approach to automated decomposition of volumetric mesh. Computers \& Graphics, Vol. 35, No. 3, pp. $461-470$.

[13] GHOSH, M., AMATO, N.M., LU, Y., LIEN, J. (2013). Fast approximate convex decomposition using relative concavity. Computer-Aided Design, Vol. 45, No. 2, pp. 494 - 504. 
[14] TOH, C.K. (2004). A study of the effects of cutter path strategies and orientations in milling. Journal of Materials Processing Technology, Vol. 152, No. 3, pp. 346-356.

[15] LAUWERS, B., LEFEBVRE, P. P. (2006). Five-axis Rough Milling Strategies for Complex Shaped Cavities based on Morphing Technology. Annals of the CIRP Vol. 55 No. 1, pp. $59-62$.

[16] ČUBOŇOVÁ, N.: Počítačová podpora pro programování řídicího systému SINUMERIK 840D, Strojírenská technologie, February, April 2012, Vol. XVII., No. 1, 2, p. 8-13, ISSN 1211-4162.

Paper number: M201222 